Journal of Engineering and Applied Sciences 14 (Special Issue 7): 9984-9988, 2019

ISSN: 1816-949X

(c) Medwell Journals, 2019

\title{
Evaluation Drinking Water of Some Plants and Some Types of Packaged Drinking Water and Imported in the Province of Karbala, the Efficiency of Markets
}

\author{
${ }^{1}$ Abbas T. Khlaif and ${ }^{2}$ Wafaa S. H. AL-Nasrawi \\ ${ }^{1}$ Department of Environmental Pollution, College of Environmental Sciences, \\ AL-Qasim Green University, AL-Qasim, Iraq \\ ${ }^{2}$ Department of Pathological Analysis Techniques, AlSafwa University College, Karbala, Iraq
}

\begin{abstract}
Water pollution is one of the major problems that affect human health, environmental systems and civilization development. Recent research shows that $71 \%$ of the world's population still suffers from contaminated water. Samples of drinking water were collected locally (Al-Waha, Al-Alaa and Nawar) as well as samples of drinking water imported (Japanese, French and Turkish). The samples were transferred to the laboratories of the directorate of the Holy Karbala environment. Some factors were measured such as $\mathrm{pH}$, turbidity, electrical conductivity, total soluble solids, calcium, magnesium, sodium, potassium and chlorides. As well as the total count of bacteria and total coliform and fecal coliform. The results are compared with the Iraqi and international standards. Some parameters differed from the recorded readings on local and imported drinking water containers if the difference was clear while others were close to the recorded readings while others were identical to the readings recorded on the packages. Bacterial test were all within the limits allowed except total bacteria count was outside the specifications allowed by Iraq and the world for local and imported water samples of the two companies Alaa and the Japanese type.
\end{abstract}

Key words: Karbala, conductivity, potassium, recorded, parameters, civilization

\section{INTRODUCTION}

Water is the largest environmental system on Earth, accounting for $71 \%$ of its area and $97 \%$ of the water is in the ocean and is not potable. Freshwater accounts for only $3 \%$ of water including lakes, rivers, groundwater and snow. The small percentage of fresh water plays a key role in the existence of life because it is the most suitable water source for public needs and is a low-cost system for the disposal of waste water and plant waste (Odum, 1971).

Drinking water is a necessary and continuous human needs which can not be dispensed for any reason and must meet the standards of water quality in terms of taste and color in addition to physical, chemical and biological specifications undesirable changes in the physical, chemical or life characteristics of water that are reduced from the validity of water, adversely affecting human and aquatic life by water pollution (Odum, 1971).

Water pollution can also be defined as undesirable environmental changes through direct or indirect effects for transformations in energy patterns, levels of radiation, physical or chemical composition or abundance of organisms.

Water pollution is one of the major problems that affect human health, environmental systems and civilization development. Recent research shows that 71\% of the world's population still suffers from contaminated water (WHO, 2008).
In the last decades, the bottled water industry has flourished and its demand has increased in most parts of the world. The quantity consumed in 2004 was 154 billion liters an increase of $57 \%$ over 98 billion liters of bottled water consumed in 1999. The reasons for this turnout are different, perhaps the most important of which is the quality of the bottled water and the regularity of this quality according to the seasons while the water of the commoners networks changes in quality with the change in the quality of the raw source water and the possibility of contamination during transportation during the pipes and reservoirs networks.

In Iraq, the bottled water industry has expanded in the last 10 years very much. "Iraqi consumers rely mainly on packaged water in various plastic containers, some of which are disposable and others are used frequently (WHO, 2001). This study evaluated the efficiency of some of the water plants stations as well as the assessment of the quality of the water locally packed and imported in Karbala governorate to compare them and to know the best species.

Aims of the study: Evaluation of the quality and finesse water of some plants in Karbala governorate and some locally produced bottled water and some imported items available in the local markets by examining some of the physical and chemical properties of these items.

Correspoding Author: Abbas T. Khlaif, Department of Environmental Pollution, College of Environmental Sciences, AL-Qasim Green University, AL-Qasim, Iraq 
Comparison of the results of the sampling with the Iraqi and international standards and comparing them with the specifications mentioned on the packaging by the producing companies.

Detection of the level of bacterial contamination of all three types of water by performing some bacterial tests by examining the most likely number of total coliform and detection of fecal coliform bacteria.

\section{MATERIALS AND METHODS}

Collection of samples: Samples of drinking water were collected locally (Al-Waha, Al-Alaa and Nawar) as well as samples of drinking water imported (Japanese, French and Turkish). The samples were transferred to the laboratories of the Directorate of the Holy Karbala Environment while samples of plant (Kabala Al Muwhd, Hussein city, Albhdry) taker reading from Directorate water of the holy Karbala. Measure the following tests:

\section{Physical and chemical analysis}

Total Dissolved Solid (TDS): Were measured using the TDS model HI9811-5 and the result was mg/L.

Electrical Conductivity (EC): Was measured using the EC Meter Model HI9811-5)) and express the output by microsimens/cm ( $\mu \mathrm{s} / \mathrm{cm})$. The 3-pH was measured using the HI9811-5 pH measurement device.

Chloride: The method of calibration with silver nitrate used to estimate the concentration of chloride ion (APHA et al., 2003).

Turbidity: Was measured using a turbidity meter (lp2000) to measure the turbidity and expressed the results in the Nephlometric Turbidity Unit (NTU).

Total hardness and calcium hardness magnesium: were measured using by calibration and expressing the results in mg/L units (APHA, 1975 ).

Sodium and potassium: were measured by the PFP7 Flame photometer (PFP7) and expressed in mg/Lunits (7).

\section{Bacteriological tests}

Determination of Total Bacterial Count (TBC): The pour plate method, described by the American Public Health Association (APHA et al., 2003, APHA., 1975) was used to estimate the total number of bacteria.

Total number of Coliform (TC) and total number of Fecal Coli form (FC): Multiple-tube technique was used to calculate the total number of coliform and Fecal Coli form (FC) to estimate the Most Probable Number (MPN) identified by the American Public Health Association.

\section{RESULTS AND DISCUSSION}

Table 1 Measuring some chemical and physical standards for public, local and imported drinking water in Karbala governorate (Fig.1-10). Table 2 Measurement of some bacteriological parameters of public, local and imported drinking water in Karbala governorate.

Physical and chemical properties of water are important in determining the validity of water whether it is river or drinking water (Hassan et al., 2008). Its importance comes from its association with each other and with the microscopic microorganisms found in water (WHO, 1997).

Physical and chemical factors of water are particularly important in determining their suitability for human use or by influencing sterilization processes and other water recipes.

The change in $\mathrm{pH}$ value will affect the chemical activity of the human body. The $\mathrm{pH}$ value of liquids within the human body ranges from 7.0-7.2. The decrease in the $\mathrm{pH}$ value of 6.4 causes the difficulty of absorbing vitamins and disrupting the enzymes and its height of 8.5 makes the taste of water tart.

The results indicated in Table 1 that all the results of ph values of drinking water samples of the public network, imported and local were within the Iraqi and global permitted limits, except for the sample of drinking water of the Japanese type and sample of Alaa drinking water. Almost 9:30 for both of them were higher than the values shown on the cover of the two packages of the two companies.

Turbidity is one of the important variables that must be taken into consideration when evaluating water for drinking purposes because of the possibility of metal elements between the suspended minutes that harm the health of the consumer as well as the efficiency of the work of the treatment units. The results in Table 1 showed that the turbidity values of all the samples were within the standard specifications except the samples of Al-Bahadari project and Al-Hussein city project were outside the standard specifications as 10 and 8, respectively.

The reason for the different of the turbidity values is due to the difference in the source of water supplied to the treatment system and the inefficiency of the treatment systems (Al-Fraij et al., 1999; Anonymous, 2007).

As for electrical conductivity, the results showed that all types of samples were within the limits allowed except for all water type of public drinking stations as well as the quality of imported drinking water of the French type as shown in Table 1. 
J. Eng. Applied Sci., 14 (Special Issue 7): 9984-9988, 2019

Table 1: Measuring some chemical and physical standard for public local and imported drinking water in Karbala governorate

\begin{tabular}{|c|c|c|c|c|c|c|c|c|c|}
\hline Samples & Chapin type & French type & Turkish type & Al Wah & Alaa & Nwara & Kabala al muwhd & Hussein city & Albhdry \\
\hline ph & 9.30 & 7.70 & 8.50 & 8.00 & 9.30 & 7.50 & 7.8 & 7.9 & 7.9 \\
\hline $\begin{array}{l}\text { Turbidity } \\
\text { NTU }\end{array}$ & 0.00 & 0.00 & 0.00 & 0.00 & 0.00 & 0.00 & 10 & 8 & 4 \\
\hline $\begin{array}{l}\text { Conductivity } \\
\mu \mathrm{S} / \mathrm{cm}\end{array}$ & 200.00 & 581.00 & 123.00 & 207.00 & 163.00 & 105.00 & 1163 & 1182 & 1167 \\
\hline TDS & 133.00 & 381.00 & 81.00 & 131.00 & 110.00 & 70.00 & 738 & 748 & 740 \\
\hline $\begin{array}{l}\text { Total hardness } \\
\text { as } \mathrm{CaCO}_{3} \mathrm{mg} / \mathrm{L}\end{array}$ & 43.00 & 326.00 & 65.00 & 92.00 & 37.00 & 29.00 & 404 & 416 & 404 \\
\hline $\begin{array}{l}\text { Magnesium } \\
\left(\mathrm{Mg}^{+2}\right) \mathrm{mg} / \mathrm{L}\end{array}$ & 5.00 & 29.00 & 3.00 & 20.00 & 3.00 & 2.00 & 30 & 33 & 29 \\
\hline $\begin{array}{l}\text { Calcium } \\
\left(\mathrm{Ca}^{+2}\right) \mathrm{mg} / \mathrm{L}\end{array}$ & 8.00 & 82.00 & 20.00 & 2.00 & 10.00 & 8.00 & 112 & 112 & 114 \\
\hline $\begin{array}{l}\text { Sodium }\left(\mathrm{Na}^{+}\right) \\
\mathrm{mg} / \mathrm{L}\end{array}$ & 7.40 & 22.80 & 1.40 & 1.00 & 19.40 & 9.00 & 88 & 89 & 82 \\
\hline $\begin{array}{l}\text { Chloride (Cl-) } \\
\text { mg/L }\end{array}$ & 16.00 & 14.00 & 4.00 & 5.00 & 20.00 & 11.00 & 112 & 124 & 112 \\
\hline $\mathrm{K}+\mathrm{mg} / \mathrm{L}$ & 0.70 & 0.50 & 0.60 & 5.70 & 0.60 & 0.30 & 3.8 & 3.8 & 3.4 \\
\hline
\end{tabular}

Table 2: Some bacteriolgical parameters of public local and impoted drinking water

\begin{tabular}{lccccccccc}
\hline Type & Chapin type & French type & Turkish type & AL wahaa & Alalaa & Alnwaraa & Kabala al muhds & Hussein city & Albhdry \\
\hline TBC & Full & 0 & 0 & 0 & Full & 0 & 0 & 0 & 0 \\
TC & 0 & 0 & 0 & 0 & 0 & 0 & 0 & 0 & 0 \\
FC & 0 & 0 & 0 & 0 & 0 & 0 & 0 & 0 \\
\hline
\end{tabular}

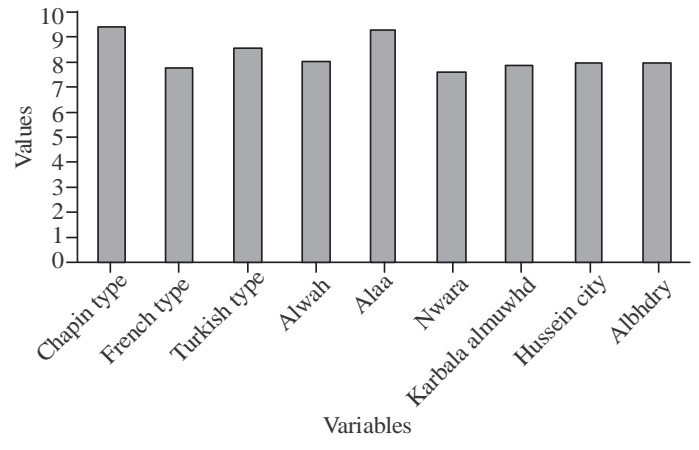

Fig. 1: ph value in water samples

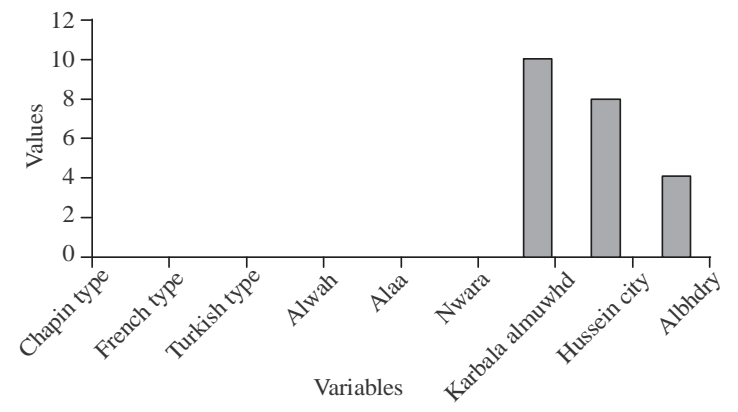

Fig. 2: Turbidity value (NTU) in water samples

Total dissolved solids include all non-organic salts and some soluble organics such as calcium, magnesium, sodium, potassium, carbonate, chloride, sulfur and nitrate salts. The quantity and amount of soluble and non-dissolved substances found in water are widely varied and may contain oxygen-absorbing substances and disease causing factors.

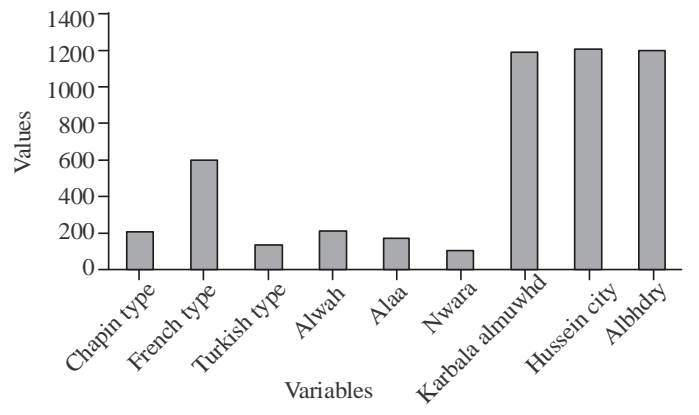

Fig. 3: Conductivity (uS/cm) in water samples

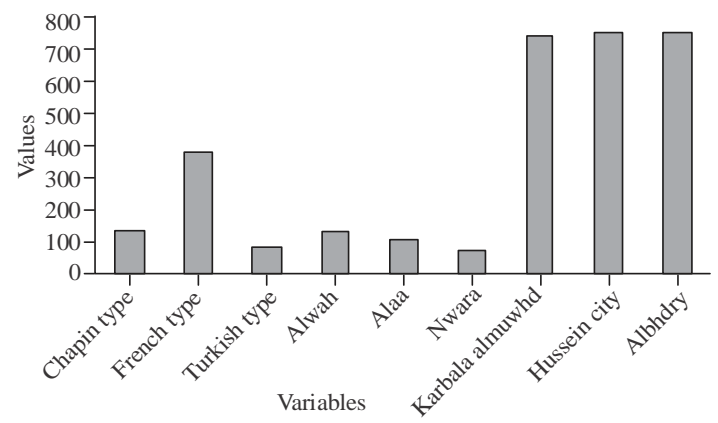

Fig. 4: TDS (mg/L) in water samples

Increased solids dissolved in drinking water cause unwanted taste that requires high efficiency and high cost treatment. The results of the research indicated in Table 1 that the total soluble solids values for public drinking water were higher than the total dissolved solids values for local and imported drinking water a one of the reasons for the different concentrations in all samples is the 


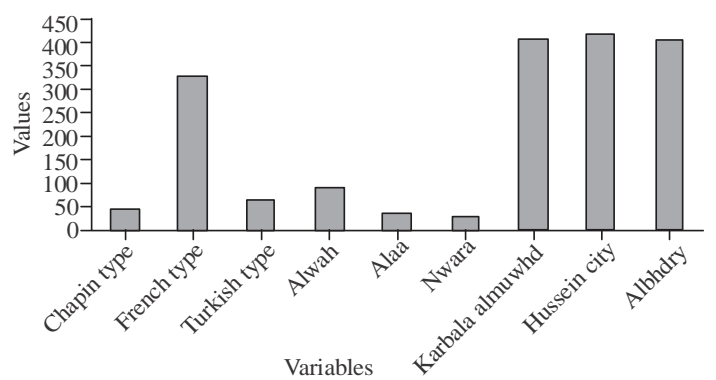

Fig. 5: Total hardness ad $\mathrm{CaCo}_{3} \mathrm{mg} / \mathrm{L}$ water samples

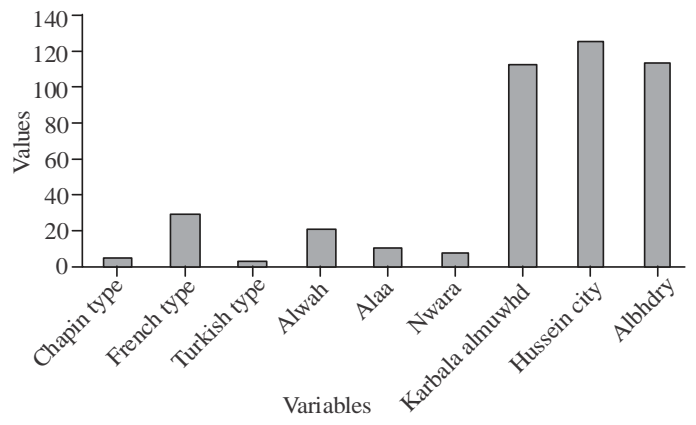

Fig. 6: Calcium $\left(\mathrm{Ca}^{+2}\right) \mathrm{mg} / \mathrm{L}$ in water samples

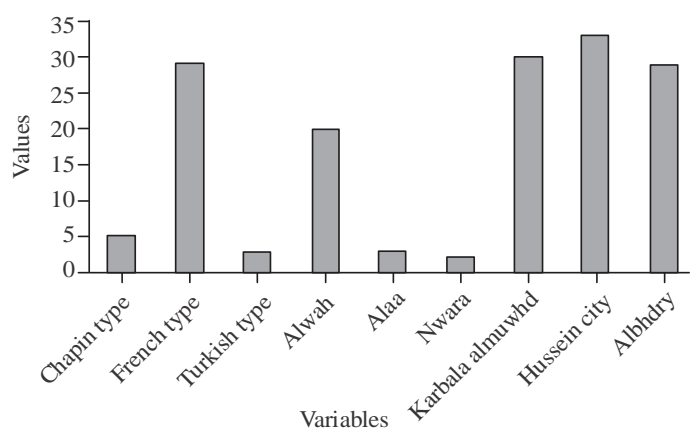

Fig. 7: Magnesium $\left(\mathrm{mg}^{+2}\right)(\mathrm{mg} / \mathrm{L})$ in water samples

efficiency of the treatment system and the effect of agricultural fertilizers in the source water which is characterized by its high content of dissolved salts (Anonymous, 2007) but all values were within the limits allowed.

Estimation of total hardness depends on the concentration of calcium and magnesium ion, an important variable in the quality of drinking water. Two types of hardening are temporary titration caused by calcium and magnesium bicarbonate and permanent hardness caused by calcium, chlorides, calcium nitrate and magnesium, the results of the study showed that the values of drinking water for public drinking water were higher than those of local and local drinking water. However, all values were within Iraqi and international

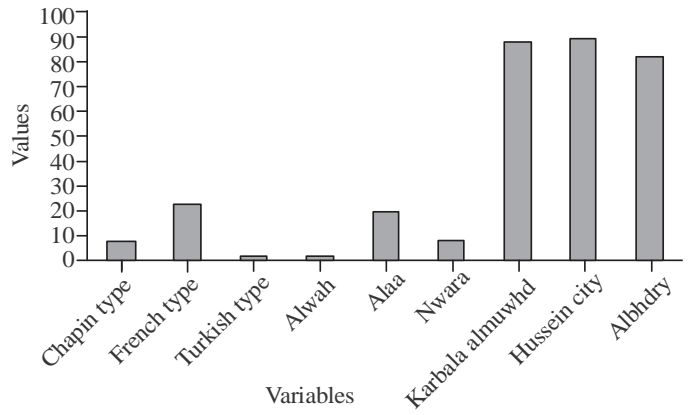

Fig. 8: Sodium $\left(\mathrm{Na}^{+2}\right) \mathrm{mg} / \mathrm{L}$ in water samples

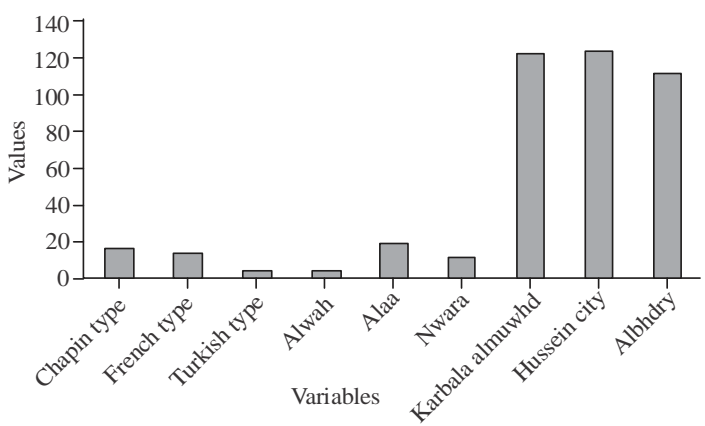

Fig. 9: Chloride $\left(\mathrm{Cl}^{-}\right) \mathrm{mg} / \mathrm{L}$ in water samples

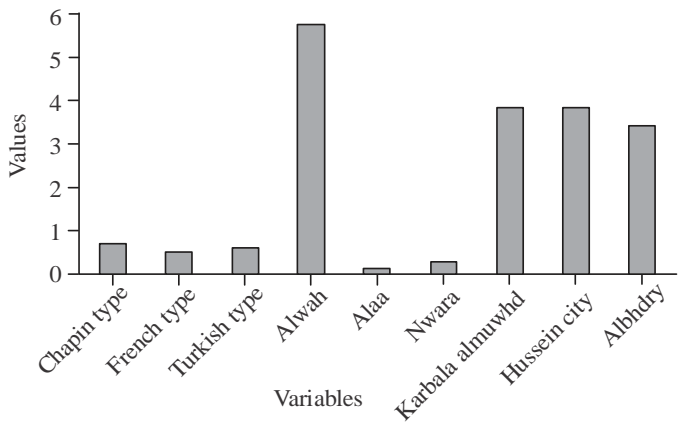

Fig. 10: $\mathrm{K}^{+} \mathrm{mg} / \mathrm{L}$ in water samples

standards. Magnesium has shown the results Table 1 all the values of magnesium for all types of water were within the specifications of Iraq and the world allowed.

Calcium is the largest mineral element its presence in the body. It consists of 2-1.5\% of body weight and 99\% of it is found in bones and teeth while the rest is distributed in plasma, body fluids and other tissues, physiological functions of calcium: formation and building of bones and teeth, the results showed that (1) the calcium values of public drinking water were higher than the calcium values of bottled drinking water but were within the limits allowed for all types of samples. 
J. Eng. Applied Sci., 14 (Special Issue 7): 9984-9988, 2019

Table 3: International and Iraqi standards for drinking water

\begin{tabular}{lllll}
\hline Characters & Iraq 2001 & Iraq 2009 & WHO 2008 & EU 2008 \\
\hline Ph & $6.5-8.5$ & $6.5-8.5$ & $6.5-9$ & $6.5-8.5$ \\
Turbidity NTU & 5 & 5 & $<5$ & Accepted \\
Conductivity & - & - & 250 & - \\
$\mu \mathrm{S} / \mathrm{cm}$ TDS & 1000 & 1000 & 1000 & - \\
Total hardness as $\mathrm{CaCO}_{3} \mathrm{mg} / \mathrm{L}$ & 500 & 500 & $150-500$ & - \\
Magnesium $\left(\mathrm{Mg}^{+2}\right) \mathrm{mg} / \mathrm{L}$ & 50 & 100 & & - \\
Calcium $\left(\mathrm{Ca}^{+2}\right) \mathrm{mg} / \mathrm{L}$ & 50 & 150 & $100-300$ & - \\
Sodium $\left(\mathrm{Na}^{+}\right) \mathrm{mg} / \mathrm{L}$ & 200 & 200 & 200 & - \\
Chloride $(\mathrm{Cl}-) \mathrm{mg} / \mathrm{L}$ & - & - & $25-200$ & - \\
$\mathrm{K}+\mathrm{mg} / \mathrm{L}$ & - & - & $10-12$ & - \\
Total coli form cell/ml L & - & - & - & 0 \\
Fecal coli form cell/ml L & - & - & \\
\hline
\end{tabular}

Sodium concentration varies in hard water as it is high concentrated in hard water that increased concentrations in water cause severe poisoning and cause vomiting, convulsions and dehydration in children (Spellman, 1998).

The results showed that (1) the sodium values of public drinking water were higher than the sodium values of bottled drinking water but were within the permissible limits for all samples. As for chlorides, the results showed that all samples were within the limits allowed. Potassium is an essential element in the synthesis of living fluids, especially, blood and its increased concentration leads to a feeling of vomiting or muscle spasm and heart rhythm disturbance. The type of soil surrounding the water source is one of the most important causes, the high concentration of potassium in the source water used as well as the efficiency of the treatment unit used and drug residues (Al-Fraij et al.,1999) (Table 3). The results showed (1) that the potassium values of public drinking water and bottled drinking water were within the permissible limits.

Total Coliforms (TC) and Fecal Coliforms (FC) are used as evidence of contamination because coliform bacteria are internationally recognized in the assessment of microbial quality of water. Fecal coliforms have been shown to be the most reliable indicator of fecal contamination of water (Fernandez-Alvarez et al., 1991).

\section{CONCLUSION}

The World Health Organization (WHO) has stipulated that drinking water should be free from harmful microscopic organisms and the presence of certain organics in water may be a suitable cause for the growth and reproduction of these organisms.

The results of bacterial testing were all within the permissible limits except total bacteria count test was outside the specifications allowed by Iraq and globally for the company of the highest and the Japanese type (Gottlieb et al., 1982; Hassan et al., 2008).

\section{REFERENCES}

APHA, AWWA, WPCF, 2003. Standard Methods for Examination of Water and Wastewater. 20th Edn., American Public Health Association, Washington, DC.

APHA., 1975. Standard Methods for the Examination of Water and Wastewater. 14th Edn., American Public Health Association, Washington, DC. USA.,.

Al-Fraij, K.M., M.K. Abd-Elaleem and H. Ajmy, 1999. Comparative study of potable and mineral waters available in the State of Kuwait. Proceedings of the WSTA 4th Conference on Gulf Water, February 13-18, 1999, State of Bahrain, pp: 253-264.

Anonymous, 2007. Wellcare information for you about Total Dissolved Solids (TDS). WellCare Health Care Company, Tampa, Florida, USA.

Fernandez-Alvarez, R.M., S. Carballo-Cuervo, M.C.D.L. Rosa-Jorge and J.R.D. Lecea, 1991. The influence of agricultural run-off on bacterial populations in a river. J. Appl. Bacteriol., 70: 437-442.

Gottlieb, M.S. and J.K. Carr, 1982. Case-control cancer mortality study and chlorination of drinking water in Louisiana. Environ. Health Perspect., 46: 169-177.

Hassan, F.M., N.F. Kathim and F.H. Hussein, 2008. Effect of chemical and physical properties of river water in Shatt Al-Hilla on phytoplankton communities. J. Chem., 5: 323-330.

Odum, E.P., 1971. Fundamentals of Ecology. 3rd Edn., W.B. Saunders Company, Philadelphia, Pennsylvania, USA., Pages: 574.

Spellman, F.R., 1998. The Science of Water: Concepts and Applications. 1st Edn., CRC Press, Boca Raton, Florida, USA., ISBN-13:978-1566766128, Pages: 256.

WHO, 2008. Guidelines for Drinking Water Quality. 3rd Edn., World Health Organization, Geneva.

WHO., 1997. Guideline for Drinking Water Quality. 2nd Edn., World Health Organization, Geneva, Switzerland, ISBN:9241545038,.

WHO., 2001. Guidelines for Drinking Water Quality: Addendum Microbiological Agents in Drinking Water. World Health Organization, Geneva, Switzerland, September 20, 2019. 